\title{
Rethinking power and law: Foucault's Society must be Defended
}

\section{Jacques de Ville}

\begin{abstract}
Michel Foucault provides a radical challenge to the liberal approach to power and law, which is echoed by Jacques Derrida. Important differences exist between the analyses of Foucault and Derrida which should not be overlooked. This essay proceeds on the basis of an awareness of these differences, yet it at the same time attempts to bring these thinkers closer together, with reference specifically to the thinking of Freud. It is often said that Foucault does not offer an alternative to that which he criticises or that his analyses do not provide for a way in which to escape from the effects of power. By specifically focusing on Foucault's reliance on the notion of 'play' in Society must be defended, it is submitted that an 'escape' is in fact provided for. The deconstructive reading of Foucault which is presented here attempts to ensure that Foucault does not remain trapped within metaphysics.
\end{abstract}

Keywords Foucault - Derrida - Freud - Biopower - Disciplinary power - Play Death

\section{$1 \quad$ Introduction}

Michel Foucault is probably the most well-known figure in the $20^{\text {th }}$ century to have questioned the way in which power is assessed. In this essay, Foucault's views on power, law and sovereignty will be enquired into through a close reading of his Lectures at the Collège de France from 1975-1976 with the title Society must be defended [17]. This reading will take place through a kind of deconstructive lens. In the present context, this entails simply that certain aspects of Foucault's analysis, which have hitherto been underemphasised, and which, as will be argued, make Foucault's analysis possible and at the same time ruins it, will be brought to the fore. The reading of Foucault undertaken here is aimed at assisting us in contemplating how we should think of power and law today. Are these for example to be viewed in terms of a tension between freedom and order as provocatively suggested in the call for papers of this Roundtable? I quote:

The overall aim of a state is to protect the social order in which the individual liberty of the citizen is a major concern. As a consequence the state should guarantee simultaneously and paradoxically a high level of individual freedom and an order in which such freedom is made possible and guaranteed.

As is well-known, Foucault provides a radical challenge to this way of thinking about rights and power. He specifically distances himself from the liberal notion of rights because of its inability to provide a challenge to disciplinary power, and calls elusively 
for the recognition of a "non-disciplinary power" or a "new right" in order to challenge disciplinary power [17, p. 40]. The reading presented here will specifically enquire into this call by Foucault, by contemplating his analysis of the limitations inherent in the liberal and Marxist discourses on power as well as in the contractoppression and war-repression schemas of power. As will be shown, Foucault draws especially from the latter schema in coming to a new understanding of power. This is of course familiar terrain for Foucauldian scholars, but it needs to be traversed here again briefly in order to arrive at the reading to be proposed, that is, that Foucault glimpsed an escape from and the possibility of resistance to the hold of power through the recognition of a "new right" or rather, as we will see, a "new law". This new law involves what Foucault refers to as "play" (jeu), a form of play entailing absolute risk and no return to the self.

\section{Foucault on power, war and law}

The analysis which Foucault undertakes in relation to power in Society must be defended concerns itself specifically with the mechanisms, effects, and relations "of the various power-apparatuses that operate at various levels of society, in such very different domains and with so many different extensions" [17, p. 13]. According to Foucault, the liberal-juridical conception of political power stemming from the $18^{\text {th }}$ century, and certain Marxist conceptions are all characterised by 'economism'. Foucault describes the classic juridical theory as viewing power -

as a right which can be possessed in the way one possesses a commodity, and which can therefore be transferred or alienated, either completely or partly, through a juridical act that founds a right...thanks to the surrender of something or thanks to a contract [17, p. 13].

In this model, Foucault continues, power "is the concrete power that any individual can hold, and which he can surrender, either as a whole or in part, so as to constitute a power or a political sovereignty" [17, p. 13]. Power is thus treated similar to a commodity. ${ }^{1}$ In Marxism, power likewise has a certain economic functionality, although different from the liberal model in the sense that it is viewed as perpetuating the dominance of a certain class and as determining relations of production. In Marxism, political power in other words finds its historical raison d'être in the economy [17, p. 14]. Foucault raises a number of questions in relation to these conceptions which all effectively subject power to the economy: Is power indeed secondary to the economy, serving it, as these approaches suggest? Can power be possessed like a commodity or viewed in terms of an exchange of goods as is implied in the juridical theory? Foucault does not with these questions mean to imply that there is no relation between the economy and power. For him they are in fact

\footnotetext{
${ }^{1}$ Later in the Lectures, Foucault [17, pp. 194-197] points out that the social contract is based on the idea of the savage as exchanger: "[T]he savage is essentially a man who exchanges. He is the exchanger: he exchanges rights and he exchanges goods. Insofar as he exchanges rights, he founds society and sovereignty. Insofar as he exchanges goods, he constitutes a social body which is, at the same time, an economic body." (p. 194)
} 
indissociable, although this relation is importantly not one of functional subordination or of a one-to-one correspondence.

In looking for alternatives to these economic approaches to power, Foucault points out that power could in the first place be viewed as the deployment of a relation of force, as repressive, either of nature, of instincts, of a class or of individuals $[17$, p. 15]. Power in this approach, as proposed by many contemporary theories, is thus essentially repressive. Foucault credits Hegel, Freud and Wilhelm Reich as having been the first thinkers to have advanced this idea. In this approach, an analysis of power becomes the analysis of the mechanisms of repression, an approach which Foucault does not however find particularly attractive [17, pp. 17-18]. As he points out later, this is because it essentially remains a "juridico-disciplinary notion", as it continues to imply "a juridical reference to sovereignty and a disciplinary reference to normalization" [17, p. 40]. The reference to Freud is particularly interesting, ${ }^{2}$ and we will return to it below. A second possibility is to view power in term of conflict, confrontation and war. Power would then be the continuation of war by other means, and, inverting Clausewitz's proposition, ${ }^{3}$ politics, the continuation of war by other means [17, p. 15]. Somewhat different from what is asserted on the back page of the English translation, this is not, or at least no longer, Foucault's contention, but on Foucault's reading that of Nietzsche, and in a sense, Boulainvilliers [17, pp. 16, 17]. This second method of analysis implies that presently existing power relations in society are a consequence of an earlier, historically determined war which established a disequilibrium of forces [17, p. 15]. Politics would then in a way be sanctioning and perpetuating this earlier established relationship of force. It also means that the political struggles of today and the reversals of power that take place, are simply in a more muted form a continuation of the same earlier war. Foucault sees a close relation between these two alternative approaches to the question of power; repression is after all, as he notes, the political outcome of war. He consequently refers to them, in combined mode, as the war-repression schema [17, pp. 16-17]. It is characterised by an opposition between struggle and submission. This is the approach which Foucault, on his own admission, relied on in his analyses preceding Society must be defended, including his History of madness and Discipline and punish [17, pp. 17-18]. Through a genealogical analysis of the development of these discourses, he now wants to explore a different kind of approach to power. The juridical approach, which Foucault explores in some detail in Lecture 2, with its view of power as a commodity, which can be transferred and held by someone, and which can in turn be abused or its limits exceeded, leading to oppression, Foucault terms the contract-oppression schema [17, pp. 16-17].

\subsection{The contract-oppression schema}

Foucault investigates in Lecture 2 the interrelation between power, right and truth. Insofar as power and right are concerned, he points out that the traditional way of

\footnotetext{
${ }^{2}$ In a footnote, the editors refer to The unconscious, The future of an illusion, and Civilization and its discontents; Freud [19, XIV pp. 159-215; XXI pp. 1-145].

${ }^{3}$ That is, that war "is a mere continuation of politics by other means".
} 
analyzing power has ever since the Middle Ages been tied to the monarch. The analyses of power made in this respect had as aim the justification of the power of the monarch. In the Western world, Foucault asserts, "right is the right of the royal command" [17, p. 25]. The reactivation of Roman law, according to Foucault, had a similar aim. It was one of the instruments that were used to establish the power of the monarch. When the conceptual structure of law was later turned against the monarch, it was destined to concern itself with the limits of the monarch's power. Foucault consequently views Western law as essentially concerned with the power and rights of the king, as well as the limits thereto, even when the monarch is eventually displaced by the people. 4 To illustrate this, one could refer to Locke who, in accordance with the social contract model, views power as a "primal right that is surrendered, and which constitutes sovereignty, with the contract as the matrix of political power" [17, pp. 16-17]. Where power oversteps its limits, or the limits of the contract, it stands in danger of becoming oppression.

As noted above, Foucault argues for the abandonment of the juridical model of sovereignty in the analysis of power relations. Law understood in the broad sense, that is, including its apparatuses, institutions and rules, which he refers to as le droit, is for Foucault a vehicle of relations of domination and of techniques of domination [17, p. 27; 15, p. 24]. This is of course self-evident, he notes. What needs to be shown are the ways in which law serves as a vehicle for such domination. This domination furthermore is not in the form of the one (the sovereign) over the many (as in political liberalism) or of one group (such as the bourgeoisie, in Marxism) over another, but has multiple forms. An analysis of power which focuses on the question of legitimacy (of the sovereign) or which in reductionist fashion traces everything back to ownership of the means of production does not therefore stand a chance of detecting these other forms of domination. Thus, confining ourselves again to the juridical model, one of the drawbacks of this model in analyzing power lies in the fact that it presupposes that power is exercised primarily through the law and that there is a centre of power, either in the monarch or his replacement in more recent times, the nation-state. To put it somewhat differently, Foucault contends that the emphasis which legal scholars, in their analyses of law, continue to place on sovereignty is based on the assumption that sovereignty equals power or that sovereignty is the source from which power springs [17, p. 45]. Foucault's analysis is concerned with the illustration that power cannot be viewed as such any longer. Power is not something that can be possessed and which can be applied to individuals by a sovereign, but is instead something that passes through individuals [17, p. 29]. The individual is consequently an effect and a relay of power rather than in opposition to power. The individual is not in other words to be thought of as inert matter to which power is applied, but as a power-effect [17, pp. 29-30].

\footnotetext{
${ }^{4}$ Should one restrict Foucault's analysis to public law? This is to be doubted. His analysis implies that the rights of subjects vis-à-vis each other, similarly find their justification in the sovereign whose courts have the function of judging these claims. Foucault [17, p. 27] also notes explicitly that the reciprocal relations between citizens in society are part and parcel of the domination that is exercised in society and which right (understood in the broad sense to be indicated) serves as a vehicle for.
} 
Foucault contends that developments in the $17^{\text {th }}$ and $18^{\text {th }}$ centuries have led to the destruction or unravelling of sovereignty, yet it has lived on as ideology and organizing principle of juridical codes [17, pp. 35-37]. The theory of sovereignty, Foucault points out, is directly based on the form of power that is exercised in feudalism in relation to land and the produce of such land. The new mechanism of power that was introduced at the time replaced this with control over bodies and what they do through a method of continuous and permanent surveillance. Foucault refers to this new form of power as non-sovereign in nature and as 'disciplinary power'. Whereas the discourse of sovereignty lays down a code of law, the discourse of disciplinary power involves a code of normalization [17, p. 38]. The reason for the continuing reliance on the theory of sovereignty in discourse lies in the fact (a) that it paradoxically provided a critical instrument against sovereignty and other obstacles at the time of the development of the disciplinary society and (b) that it could be used to establish (sovereign) rights for individual subjects while at the same time concealing the mechanisms of disciplinary power, its element of domination and the techniques it employs [17, p. 37]. This combination of a discourse of sovereignty and disciplinary power, Foucault notes, was aimed at ensuring the cohesion of the social body. These two discourses, in their intersection, that is, the invasion and colonizing of law in the broad sense by disciplinary power, produce what Foucault refers to as a "normalizing society" [17, p. 39].

In struggling against disciplinary power, Foucault points out that the only form of resistance that appears to be available is reliance on right or law in the broad sense, which as we saw is derived from the theory of sovereignty. This is however ineffective in limiting the effects of disciplinary power. What we should do instead is to search for a non-disciplinary power or a new right. In the words of Foucault:

Truth to tell, if we are to struggle against disciplines, or rather against disciplinary power, in our search for a nondisciplinary power, we should not be turning to the old right of sovereignty; we should be looking for a new right [un nouveau droit] that is both anti-disciplinary and emancipated from the principle of sovereignty [17, pp. 39-40].

\subsection{The war-repression schema}

For reasons of space a detailed account cannot be given here of Foucault's lengthy analysis in Lectures 3 to 10 of the war-repression schema, which he traces to the $16^{\text {th }}$ and $17^{\text {th }}$ centuries. 5 Up until the rise of this counter-discourse, history had been in the service of sovereign power, Foucault contends, playing the role of justifying such power and enforcing it [17, p. 66]. History, one could say, furnished proof of the uninterrupted nature of the right of the sovereign, an approach which was also practiced in Roman society [17, pp. 67-69]. In the $16^{\text {th }}$ century, a counter-discourse however develops of what Foucault [17, p. 111] refers to as "political historicism",

\footnotetext{
${ }^{5}$ Foucault at times refers to the $17^{\text {th }}$ and $18^{\text {th }}$ centuries as the period in which this discourse commenced, but this seems to refer to the developments in France, whereas the reference to the $16^{\text {th }}$ and $17^{\text {th }}$ centuries refers to developments in England, [17, pp. 143, 271].
} 
which views politics as a continuation of war by other means. It contends that the establishment of society, law and the state does not put an end to war:

Law is not pacification, for beneath the law, war continues to rage in all the mechanisms of power, even in the most regular. War is the motor behind institutions and order. In the smallest of its cogs, peace is waging a secret war $[17$, p. 50].

The only way in which this permanent war can be brought to an end, according to those who rely on this discourse, is by way of a decisive battle with actual weapons [17, pp. 16, 51]. Foucault gives two specific examples of the adoption of this kind of historical discourse: in England at the time of the bourgeois revolution, by the Puritans, the Levellers and the Diggers, ${ }^{6}$ and in France by the reactionary French aristocracy [17, p. 49].7 Foucault finds this model attractive up to a point. This discourse after all provided the first challenge to the juridical model of sovereignty [17, p. 168]. As we will see, and this will be the focus of our further discussion, its attraction lies specifically in the insights it provides regarding the way in which power operates, which will be extremely useful to Foucault in his analysis of disciplinary power and biopower.

For Foucault this analysis is attractive, firstly because of its deviation from the ideas of speaking from a position of universality, totality or neutrality, a position which Foucault associates with the jurist and the philosopher. Those who engage in this discourse speak from a position of partiality, and the truth they speak is not a universal truth, but perspectival $\left[17\right.$, p. 52]. ${ }^{8}$ This discourse shows to Foucault $[17, \mathrm{p}$. 53] that "truth is essentially part of a relationship of force, of dissymmetry, decentering, combat, and war". This is furthermore a discourse which explains society from below, with reference to contingencies, or intertwining bodies, passions and accidents, which seeks to expose the cunning and wickedness of a rationality of technical procedures that attempts to keep in place existing relationships of force [17, pp. 54-55]. Foucault [17, p. 32] himself shows a clear preference for this kind of approach in his analysis of power which stands in stark contrast to the juridical model described above which as he points out, seeks to extract from all these contingencies "a basic and permanent rationality which is, by its very essence, bound up with fairness and the good" [17, p. 55]. A third reason for the importance of this discourse lies in the fact that it does not seek to extract certain basic and stable principles from history and does not believe that history has a final goal. It investigates actual battles, struggles and victories that have been won; it seeks to discover the "dissymmetry of forces that lies beneath the equilibrium of justice" [17, p. 56]. Fourthly, this discourse

\footnotetext{
${ }^{6}$ Hobbes is criticised by Foucault [17, pp. 110-111] for attempting to eliminate this discourse. Hobbes's analysis is more specifically based not on war as at the origin of the state, but on the avoidance of war. Here the sovereign is transferred all power in order to prevent war, to protect one's life. Hobbes's analysis, Foucault contends, makes it impossible to see that this war is still continuing.

${ }^{7}$ Medovoi [23, p. 61] contends that Foucault does not consider the impact which the relation between colonial powers and indigenous peoples may have had on the development of this discourse, but see Foucault [17, pp. 7677, 103 and 257].

${ }^{8}$ We will return to Foucault's apparent perspectivism below.
} 
combines a marginalised knowledge with a mythology which is tied to "the most insane hopes" [17, p. 57].

Foucault also finds of great importance the idea in this counter-discourse that the war which is taking place underneath peace is basically a race war, a clash between two races, a struggle for existence [17, p. 6o]. The discourse on race will play an important role in Foucault's lecture on biopower (Lecture 11) where he will develop further the idea that this race struggle developed into state racism in the $19^{\text {th }}$ and $2 \mathrm{O}^{\text {th }}$ centuries. This is no longer a struggle between two distinct races, but involves a split in the same race between a super-race and a sub-race [17, pp. 61, 82]. The super-race is of course the 'true' race, which holds power and determines the norm. The discourse is now used to exclude from and to segregate and normalize the social body. The state racism that develops in the $19^{\text {th }}$ and $20^{\text {th }}$ centuries will in a sense be directed at society itself, at its own elements and products, and will seek its own purification [17, p. 62]. The discourse of race struggle in fact developed in two directions in the $19^{\text {th }}$ century, Foucault contends. The direction described above, where race is transformed by giving it a biological and medical meaning (or what he terms "actual racism"), and the attempt to transcribe it into a history of class struggle [17, pp. 80-81, 190, 272]. Other insights which Foucault gains from this counterdiscourse includes Boulainvilliers's realisation that power cannot be possessed, as well as that historical knowledge is a weapon in the struggle concerning the truth [17, pp. 168, 171-173]. Foucault furthermore finds attractive the idea of domination which this counter-discourse established, which as we saw above should be central to the analysis of power [17, p. 111].

Why then does Foucault eventually abandon this form of analysis? The counter-discourse of politics as war by other means, as he points out, was overtaken by historical events. With the French revolution a turn came, leading to the abolition, the restriction or perhaps more accurately, the transformation of this discourse [17, pp. 236, 239]. The French revolution more specifically led to the third estate inheriting the sovereignty of the king $[17$, p. 232]. The war was won, with the bourgeoisie as the decisive victors. The third estate, as Foucault [17, p. 236] notes, now took sole control of both nation and state. For purposes of Foucault's analysis there is also an important limitation in this war-repression discourse, which makes it unsuitable for the analysis of society in the $20^{\text {th }}$ century without certain modifications. As Neal [26, pp. 389-390] points out, this limitation lies in the fact that it can be used only as a tool by means of which to critique and ultimately to attempt to seize sovereignty. It cannot escape the problem of sovereignty as such.

\subsection{Disciplinary power and biopower}

As pointed out above, the theme of race of the $18^{\text {th }}$ century is with the French revolution transformed into state racism [17, p. 239]. This development ties in with one of the most important features of the $19^{\text {th }}$ century - the hold of power over life, that is, "the acquisition of power over man insofar as man is a living being,...State control of the biological" [17, pp. 239-240]. It already started in second half of the $18^{\text {th }}$ century and involved a change in technology, mechanisms and instruments of power, 
as compared to the disciplinary power which was established at the end of the $17^{\text {th }}$ and in the course of the $18^{\text {th }}$ centuries [17, pp. 181-182, 241-242]. 9 Disciplinary power, as Foucault sets out in more detail in Discipline and punish, involves techniques of power centred on the individual body, with the primary aims of surveillance and training. Biopolitics or biopower does not replace disciplinary power, but modifies it and at the same time uses its techniques [17, pp. 242, 243]. Disciplinary power thus continues to operate even after the introduction of biopower [17, pp. 250-253]. Both forms of power are aimed at the 'normalization' of society, and as we saw above, rely on law as a vehicle in achieving this goal. Compared to disciplinary power, biopower is not directed at man-as-body, but at man-as-species, the population as such, concerning itself with issues of birth, death, illness, disability, production, the environment, etc. [17, pp. 242-247]. Foucault in this respect also refers to it as the power of regularization. Foucault's description of the way in which death is dealt with in the age of biopower is important, and we will return to it again shortly:

Death was no longer something that suddenly swooped down on life - as in an epidemic. Death was now something permanent, something that slips into life, perpetually gnaws at it, diminishes it and weakens it [17, p. 244].

With the development of biopower, the sovereign right of the king "to take life or let live" which in Foucault's view involves a startling dissymmetry (its essence lies in the right to kill) as a result undergoes an important transformation, or more precisely, comes to be complimented by something else [17, p. 240-241]. Sovereignty's right (to take life or let live) is not thereby abandoned, but is penetrated and permeated by what Foucault refers to as a "new right" (un autre droit nouveau) [17, p. 241; 15, p. 214], in this way returning to the task he set himself in Lecture 2. When read in context, what is at stake here is therefore not a new 'right' which a legal subject may lay claim to, ${ }^{10}$ but the "right" or perhaps rather "law" associated with biopower. ${ }^{11}$ As we will see, Foucault specifically enquires into the 'law' in terms of which biopower operates, in looking for a way in which a struggle can take place against disciplines [17, pp. 39-40]. This new biopower involves exactly the opposite of sovereignty's "old right", Foucault asserts: "the power to 'make' live and 'let' die" [17, pp. 241, 247]. This is because biopower intervenes "to improve life, to prolong its duration (even beyond biological death), to improve its chances, to avoid accidents, and to compensate for failings" ([17, p. 254] read with pp. 248-249). The technological power in biopolitics thus seeks to achieve "an overall equilibrium that protects the security of the whole from internal dangers" [17, p. 249]. Death nevertheless remains beyond the grasp of power, as power can deal with death only in general, statistical terms.

We reach an extremely interesting and for our purposes, important point in the determination of the 'law' of bio-power when Foucault considers the limit that is reached by biopower in the manufacturing and use of the atom bomb (as well in the

\footnotetext{
${ }^{9}$ See also Foucault [16, p. 139].

${ }^{10}$ For other, mostly critical evaluations of Foucault's notion of a new form of right, see Litowitz [22, pp. 31-32]; Pickett [28, pp. 403-421]; Patton [27, pp. pp. 282-283]; and Mourad [25]. The reading of the 'new right' proposed in the present article, ties in very closely with that of Keenan [20].

${ }^{11}$ The French 'droit' can be translated as both 'right' and 'law'.
} 
ability to create living matter). As Foucault points out, this power does not simply involve the right of the sovereign to kill millions or hundreds of millions of people:

The workings of contemporary political power are such that atomic power represents a paradox that is difficult, if not impossible, to get around. The power to manufacture and use the atom bomb represents the deployment of a sovereign power that kills, but it is also the power to kill life itself. So the power that is being exercised in this atomic power is exercised in such a way that it is capable of suppressing life itself. And, therefore, to suppress itself insofar as it is the power that guarantees life. Either it is sovereign and uses the atom bomb, and therefore cannot be power, biopower, or the power to guarantee life, as it has been ever since the nineteenth century. Or, at the opposite extreme, you no longer have a sovereign right that is in excess of biopower, but a biopower that is in excess of sovereign right. This excess of biopower appears when it becomes technologically and politically possible for man not only to manage life but to make it proliferate, to create living matter, to build the monster, and, ultimately, to build viruses that cannot be controlled and that are universally destructive. This formidable extension of biopower, unlike what I was just saying about atomic power, will put it beyond all human sovereignty [17, pp. 253-254].

This irresolvable paradox, or perhaps rather 'aporia', lies at the heart of Foucault's analysis of biopower, even though it never becomes a theme.12 Immediately after noting this, Foucault seeks the forgiveness of his audience for this 'digression', but nevertheless attempts to justify it by explaining that it "does provide us with a basic argument (fond-là: the substance/heart/root/core)" which will allow for a return to the "problem" he was trying to raise $[17$, p. $254 ; 15$, p. 226].13 As he does elsewhere in the Lectures, Foucault touches on the 'law' at stake in these processes, but then again changes direction. The 'problem' Foucault seeks to address, in light of the abovesketched 'retreat' of sovereign power and the extension of biopower, is specifically how killing operates in this context, keeping in mind that the function of biopower ultimately is to 'make live'. Foucault explains this with reference to the notion of 'racism'. The reason for Foucault's long genealogical analysis now becomes clear. What his analysis has shown is that disciplinary and bio-power ultimately and inevitably leads to (state) racism. The traditional juridical discourse is unable to address this development. In the words of Foucault:

The theory of right basically knew only the individual and society: the contracting individual and the social body constituted by the voluntary or implicit contract among individuals. Disciplines, for their part, dealt with individuals and their bodies in practical terms. What we are dealing with in this new technology of power is not exactly society (or at least not the social body, as defined by the jurists), nor is it the individual-as-body. It is a new body, a multiple body, a body with so many heads that, while they might not be infinite in number, cannot necessarily be counted. Biopolitics deals with the population, with the population as political problem, as a problem that is at once scientific and political, as a biological problem and as power's problem [17, p. 245].

This failure of the theory of right is tied to the fact that, as we saw, biopower does not deal with the individual qua individual. Intervention instead takes place at the level of

\footnotetext{
${ }^{12}$ It furthermore contrasts sharply with the perspectivist approach he seemingly adopts elsewhere in the lectures [17, p. 52]. This can now be read as simply a description of the war-repression schema, and not Foucault's own position.

${ }^{13}$ The 'problem' Foucault refers to here seems to be "the problem of war, seen as a grid for understanding historical processes" [17, p. 239].
} 
general phenomena, for example in relation to the mortality rate or the birth rate. It is no longer so much a question of discipline, but rather of regularization through the use of general mechanisms [17, pp. 246-247]. Normalization thereby becomes more important than the law, which does not mean the retreat of law. Law instead changes its function, serving normalization $[17$, p. 266].14

What then is the importance and function of racism in the context of biopower? The histories of the $18^{\text {th }}$ century, as we saw, already employed the notion of race. As was the case there, this is to be understood in terms of the nation and its interests. The development of biopower, as Foucault puts it, inscribes racism "in the mechanisms of the State.... [R]acism is inscribed as the basic mechanism of power, as it is exercised in modern states" [17, p. 254]. This notion of state racism refers to a range of distinctions which are employed to make possible a separation between the superior and the inferior within a specific population. It furthermore allows for the killing or letting die of the abnormal, the degenerate, the inferior, in order for the species as a whole to remain alive [17, pp. 254-255]. Racism in this form thus has a biological basis and does not, as was the case in the $18^{\text {th }}$ century, involve a military, warlike or political relationship. Those who need to be done away with are the individuals who constitute a threat to that population, whether they find themselves on the inside or the outside of that population [17, pp. 255-256]. Killing here refers not only to murder as such, but also to forms of indirect killing such as greater exposure to the threat of death. Political discourse is able to make the necessary distinctions by adopting ideas from biology and evolutionism in its contemplation of wars, colonization, the relation between the different classes in society, as well as in enabling it to deal with issues such as mental illness, madness, criminality and sexual deviancy [17, pp. 256-257]. War is furthermore no longer about the defeat of a political adversary, but about the destruction of an enemy race, a people that constitute a biological threat to 'our' race. From the $19^{\text {th }}$ century onwards the killing that goes along with war however involves not only the killing of the enemy race, but, and here we return to Foucault's earlier 'digression', also large numbers of one's own race, so as to purify it from within [17, p. 257]. Killing thus carries a risk, the risk of destroying also those whom one seeks to protect, manage and multiply [17, p. 258].

For Foucault, modern racism is much 'deeper' than ideology; it is bound up with available techniques of power. The state, Foucault [17, p. 258] notes, "is obliged to use race, the elimination of races and the purification of the race, to exercise its sovereign power". To fully understand what Foucault means here, it is again necessary to return to an earlier part of the text where he explains that racism is now no longer used, as in the $18^{\text {th }}$ century, as a way in which to counter sovereignty, but instead to preserve the sovereignty of the state. Magico-juridical rituals no longer guarantee this sovereignty. Instead reliance is placed on medico-normalizing techniques. Sovereignty thus takes over the discourse of race struggle and uses it as a strategy of its own [17, pp. 81-82]. As Kelly [21, pp. 66-68] points out, racism in this form needs of course not necessarily to be couched in explicit biological terms. It can also happen in other, less overt ways, for example by relying on utilitarian arguments,

\footnotetext{
${ }^{14}$ See also Foucault [16, p. 144].
} 
on values such as democracy, human rights and freedom, on security concerns or the right to self-defence, on moral rhetoric such as good versus evil, and even on altruistic rhetoric. 15

The ultimate expression ("paroxysmal point") of state racism is for Foucault to be found in Nazi society, a society underpinned by disciplinary power and biopower, whilst at the same time unleashing the old sovereign right to kill [17, p. 259]. This right was not restricted to the state, but effectively extended to everyone in this society, taking account of the 'panoptic' practice of informing on one's neighbours. We return here to one of the implications of the war-repression analysis spelt out by Foucault, and referred to earlier. The war unleashed by the Nazis was viewed by them as "a sort of ultimate and decisive phase in all historical processes - politics had to lead to war, and war had to be the final decisive phase that would complete everything" [17, p. 259]. The aim of waging war was consequently not simply to destroy other races, but, again returning to Foucault's earlier 'digression', to expose the German race to the ultimate risk. As Foucault explains:

Exposing the entire population to universal death was the only way it could truly constitute itself as a superior race and bring about its definitive regeneration once other races had been either exterminated or enslaved forever $\left[17\right.$, p. 260]. ${ }^{16}$

According to Foucault, there is an exact coincidence, an absolute coextension here between the sovereign right to take life (the life of everyone) and biopower. He finds this coincidence "really quite extraordinary" and revealingly refers to it twice as a 'play' (jeu). ${ }^{17}$ We have here, Foucault notes, 'an absolutely racist State, an absolutely murderous State, and an absolutely suicidal State [17, p. 260]. The 'final solution' therefore does not entail only the elimination of the Jewish race (as a symbol and manifestation of all the other races that had to be destroyed) but of the German race as well. This is not however a feature only of the Nazi state, but of all modern states, capitalist and socialist [17, p. 260-261]. ${ }^{18}$ Socialism, insofar as it concentrated its analysing efforts on property and the ownership of the means of production, neglected investigating biopower with the consequence that it took over wholesale the project gaining momentum in the $18^{\text {th }}$ century of managing life, in its exclusion of the mentally ill, criminals, political adversaries, etc [17, pp. 261-262]. Foucault ends his lecture with the following question:

How can one both make biopower function and exercise the rights of war, the rights of murder and the function of death, without becoming racist? That was the problem, and that, I think, is still the problem [17, p. 263].

\footnotetext{
${ }^{15}$ Kelly [21, pp. 63-64] points out that even right-wing parties tend to make use more often of the discourse of the nation (the national interest) than that of conventional racism. This is usually in the form of economism.

${ }^{16}$ See also Foucault [16, pp. 149-150].

17 "Of course, Nazism alone took the play between the sovereign right to kill and the mechanisms of biopower to this paroxysmal point. But this play is in fact inscribed in the workings of all states" [17, p. 260; 15, p. 232] (my italics).

${ }^{18}$ Foucault [17, pp. 260-261] raises some doubt as to whether this can indeed be said with certainty of all capitalist states.
} 


\section{Invoking a certain Freud}

Foucault thus ends Society must be defended by again positing an aporia. At stake in the 'relation' between biopower and death appears to be a strange kind of law. ${ }^{19}$ To explain the operation of this law in more detail, we need to return to Freud. The somewhat critical attitude that Foucault adopts in relation to Freud in the first lecture is repeated throughout Foucault's texts. At the same time there are numerous indications in Foucault's texts that this criticism is directed only at a certain Freud, that is, the Freud who places psychoanalysis in alliance with order, law and morality [6, pp. 98-99]. There is however also another Freud with whom Foucault can be said to be in close alliance with. ${ }^{20}$ This can clearly be seen from the above-quoted passages. This is the Freud who, as Derrida puts it, "talks it out with death", the Freud of the death drive, of Beyond the pleasure principle [6, p. 104; 19 XVIII, pp. 1-64]. Placed side by side with this text of Freud, Society must be defended can be read as an attempt to transcribe the implications of Freud's insights for the modern State and at the same time to find a way in which to resist 'state racism'. Foucault can more broadly be said to describe the strange relation that exists in the modern state between two desires: on the one hand for the pure, the safe, and the secure, and on the other, the desire for death, for absolute pleasure. ${ }^{21}$ This is alluded to by Foucault, not only when he speaks of the possibility of completely destroying life, and the selfdestruction of the German race, but also when he in the latter context and elsewhere invokes the notion of play (jeu). In his discussion of Boulainvilliers's analysis of societal relations in terms of a permanent war, he furthermore notes specifically that Boulainvilliers concerns himself with the problem of "how the strong became weak, and how the weak became strong" [17, p. 16o]. This is not only an empirical investigation, but has as aim "the determination of the internal mechanisms of the inversion" [17, p. 160]. In other words, it seeks to reveal a kind of 'law' which is at work behind these inversions. ${ }^{22}$

The notion of 'play' (jeu) is invoked throughout Society must be defended, for example in noting "the play of these technologies of power" $[17$, p. 31; 15, p. 28]; the fact that "power is exercised through, on the basis of, and in the very play of the heterogeneity between a public right of sovereignty and a polymorphous mechanics of discipline" [17, p. 38; 15, p. 34]; "the play between knowledge and power" [17, p. 137; 15, p. 119]; Boulainvilliers's description of the phenomenon of power "in historical terms and the play of relations of force" [17, pp. 169, 208, 225; 15, pp. 150, 186,

\footnotetext{
${ }^{19}$ Foucault also explores this 'law' elsewhere, see [18], and De Ville [14].

${ }^{20}$ In relation to Freud (and Marx) Foucault remarks specifically on the need to 'cut up, rip[] up, torn to shreds, turn[] inside out, displace[]' etc the theoretical unity of these 'all-encompassing and global theories' for purposes of providing a tool of 'critique' at the local level [17, p. 6].

${ }^{21}$ Derrida [5, pp. 257-409] explores the relation between the death drive and pleasure with reference to Freud's Beyond the pleasure principle.

${ }^{22}$ See similarly, Derrida [7, p. 226] on Nietzsche's Genealogy of morals: "When Nietzsche says that the strong have been made slaves by the weak, this means that the strong are weak, that Nietzsche comes to the rescue of the strong because they are weaker than the weak. In a certain sense, by coming to the aid of strength, Nietzsche is coming to the aid of weakness, of an essential weakness."
} 
201], ${ }^{23}$ "the play between the two grids" of historical discourse, that is, reactionary, aristocratic and rightist on the one hand, and liberal and bourgeois on the other [17, p. 229; 15, p. 204]; "the play of technologies of discipline on the one hand and technologies of regulation on the other" [17, p. 253; 15, p. 225], ${ }^{24}$ and as we saw above, "the play between the sovereign right to kill and the mechanisms of biopower" [17, p. 260; 15, p. 232].25 The notion of play in these instances could of course be read as referring to play based on a fundamental ground, play coupled with security, in the sense of an origin, a full presence [4, p. 279]. When account is however taken of the passages referred to earlier and specifically of Foucault's implicit invocation of the Freudian death drive, ${ }^{26}$ it becomes possible to understand the play which is at stake here as a play without any security, placing oneself completely at risk. ${ }^{27}$ In quasiHeideggerian terms, one could refer to it as the play of the other within being [8, p. 162]. It functions as that which sets all the different historical discourses in Foucault's analysis in motion.

Through his invocation of the notion of 'play', Foucault at the same time relativises the importance of the historical categorising which he employs in Society must be defended. Reading Foucault thus would tie in with Agamben's criticism of Foucault's limitation of biopower to modernity [1, p. 6]. Sovereignty would therefore not in a subsequent period be followed and replaced by disciplinary control and thereafter by biopolitics [1, p. 6]. There would instead be a necessary and longstanding relation between biopolitics ${ }^{28}$ and sovereignty, ${ }^{29}$ as Foucault indeed seems to confirm when he refers to the 'play' between sovereign power and biopolitics in Nazism, with the latter leading to the dissolution of sovereignty, and when he additionally notes that this is in fact a feature of all states [17, p. 260]. Foucault takes another step in relativising the importance of the historical distinctions which he draws and in recognising the conditions of possibility of these discourses when he describes the relation to death in Freudian (and Heideggerian) terms as something which is not outside of life, but precisely on the 'inside' and implicitly as that which is continuously cast out.30 The discourses which find expression in the different 'periods' which Foucault identifies, can now be understood as repeated (albeit different) attempts at casting out that which is on the inside, at securing the pure, in

\footnotetext{
${ }^{23}$ See similarly Derrida [2, p. 148] where he remarks in explaining the 'notion' of différance that for Nietzsche "force itself is never present; it is only a play of differences and quantities".

${ }^{24}$ Foucault [16, pp. 145-146] interestingly accords a similar role to sex, which as he notes "was at the pivot of the two axes along which developed the entire technology of life" (at 145); see also Foucault [17, pp. 252-253].

${ }^{25}$ Emphasis in each quotation added.

${ }^{26}$ Foucault [16, p. 156] makes a link between the death instinct and sex. He however seeks to restrict this coincidence to modernity; see also Miller [24, pp. 242-244].

${ }^{27}$ See in this regard Derrida [5, pp. 292-337; 3, pp. 50, 307]. From Freud [19, XV p. 156] we have the observation in relation to dream symbols that "[s]atisfaction obtained from a person's own genitals is indicated by all kinds of playing, including piano-playing." See further Freud [19, XXI pp. 190-194] for the link between play, gambling, masturbation and placing everything at risk.

${ }^{28}$ Biopolitics is defined broadly by Agamben so as to include disciplinary control.

${ }^{29}$ Derrida [10, p. 330] confirms this stance of Agamben. He nevertheless notes that Agamben is himself ambivalent about whether biopower is a specifically modern phenomenon or whether it has always been associated with sovereign power.

${ }^{30}$ See above. The question of life and death is of course at the centre of the discourse on biopolitics, as Derrida [10, pp. 305-334] points out.
} 
the midst of that which is absolutely 'impure', that is, the relation with death. Technology, as we saw, plays a crucial role in modern biopower: it is the mechanism through which the desire for presence is exercised, yet by means of the nuclear war which it makes possible (something which is perhaps itself desired), it at the same time exposes all life to death [9, pp. 394, 400-402].31 Viewed thus, the contemporary biopolitical discourse is then (simply) another way in which presence is sought. The desire for presence (here in the form of sovereignty), it appears, also from Foucault's analysis, however ultimately coincides with the desire for death [8, p. 164]. The return to the self of sovereignty, also in a democracy, consequently always involves the risk of self-destruction, or as Derrida puts it, echoing the words of Foucault:

no community <is possible> that would not cultivate its own auto-immunity, a principle of sacrificial self-destruction ruining the principle of self-protection (that of maintaining its selfintegrity intact), and this in view of some sort of invisible and spectral sur-vival [13, p. 51].

This appears to be another way in which to express what Foucault calls for when he talks about the "new right that is both antisdiciplinary and emancipated from the principle of sovereignty" that we should look for in our struggle against disciplinary power [17, pp. 39-40]. We are, to be sure, speaking here of absolute hospitality, beyond a circular economy [11], which puts into play with an absolute risk the restrictive discourses Foucault analyses so rigorously in Society must be defended and elsewhere.

Acknowledgements: Funding for this research was generously provided by the University of the Western Cape and the South African National Research Foundation. Gratitude is expressed to the participants in the Roundtable for their insightful comments on the paper.

\section{References}

1. Agamben, Giorgio. 1998. Homo sacer: Sovereign power and bare life. Stanford: Stanford University Press.

2. Derrida, Jacques. 1973. Speech and phenomena and other essays on Husserl's theory of signs. Evanston: Northwestern University Press.

3. Derrida, Jacques. 1974, 1976. Of grammatology. Baltimore and London: John Hopkins University Press.

4. Derrida, Jacques. 1978. Writing and difference. Chicago: University of Chicago Press.

5. Derrida, Jacques. 1987. The post card: From Socrates to Freud and beyond. Chicago and London: University of Chicago Press.

6. Derrida, Jacques. 1998. Resistances of psychoanalysis. Stanford: Stanford University Press.

\footnotetext{
${ }^{31}$ See in this respect the insightful remark of Freud [19, XXI p. 90]: "With every tool man is perfecting his own organs, whether motor or sensory, or is removing the limits to their functioning." Freud continues to give a number of examples of these, including ships, aircraft, the telescope, the microscope, the camera, the gramophone, the telephone, writing and the dwelling house. Modern science and technology, Freud (p. 91) furthermore notes, "are an actual fulfilment of every - or almost every - fairy-tale wish".
} 
7. Derrida, Jacques. 2002. Negotiations: Interventions and interviews 19712002. Stanford: Stanford University Press.

8. Derrida, Jacques. 2004. Dissemination. London and New York: Continuum.

9. Derrida, Jacques. 2007. Psyche: Inventions of the other volume I. Stanford: Stanford University Press.

10. Derrida, Jacques. 2009. The beast \& the sovereign. Chicago and London: University of Chicago Press.

11. Derrida, Jacques and Anne Dufourmantelle. 2000. Of hospitality. Stanford: Stanford University Press.

12. Derrida, Jacques and Elisabeth Roudinesco. 2004. For what tomorrow...a dialogue. Stanford: Stanford University Press.

13. Derrida, Jacques and Gianni Vattimo. 1998. Religion. Stanford: Stanford University Press.

14. De Ville, Jacques. 2010. Madness and the law: The Derrida/Foucault debate revisited. Law and Critique. 21: 17-37.

15. Foucault, Michel. 1997. Il faut defender la société: Cours au Collège de France (1975-1976). Paris: Gallimard/Seuil.

16. Foucault, Michel. 1998. The will to knowledge: The history of sexuality volume 1. London: Penguin.

17. Foucault, Michel. 2004. Society must be defended: Lectures at the Collège de France, 1975-76. London: Penguin.

18. Foucault, Michel and Maurice Blanchot. 1990. Maurice Blanchot: The thought from outside / Michel Foucault as I imagine him. New York: Zone Books.

19. Freud, Sigmund. 2001. The standard edition of the complete psychological works of Sigmund Freud. London: Vintage.

20.Keenan, Tom. 1987. The 'paradox' of knowledge and power: Reading Foucault on a bias. Political Theory 15: 5-37.

21. Kelly, Mark. 2004. Racism, nationalism and biopolitics. http://www.usyd.edu.au/contretemps/4september2004/Kelly.pdf. Accessed on 15 March 2010.

22.Litowitz, Douglas. 1995-96. Foucault on law: Modernity as negative utopia. Queen's Law Journal 21: 1-36.

23. Medovoi, Leerom. 2007. Global Society must be defended: biopolitics without boundary. Social Text 25: 53-79.

24.Miller, James. 2000. The passion of Michel Foucault. Cambridge, Massachusetts: Harvard University Press.

25. Mourad, Roger. 2003. After Foucault: A new form of right? Philosophy \& Social Criticism 29: 451-481.

26.Neal, Andrew W. 2004. Cutting off the king's head: Foucault's Society must be defended and the problem of sovereignty. Alternatives: Global, Local, Political 29: 373-398.

27. Patton, Paul. 2005. Foucault, critique and rights. Critical Horizons 6: 267-287.

28.Pickett, Brent L. 2000. Foucaultian rights? The Social Science Journal 37: 403-421. 